\begin{tabular}{c|c|c}
\hline \hline Vol. 239: 1-10, 2002 & MARINE ECOLOGY PROGRESS SERIES \\
Mar Ecol Prog Ser & Published August 23 \\
\hline
\end{tabular}

\title{
Ocean climate anomalies and the ecology of the North Sea
}

\author{
Martin Edwards ${ }^{1, *}$, Gregory Beaugrand ${ }^{1,2}$, Philip C. Reid ${ }^{1}$, Ashley A. Rowden ${ }^{3}$, \\ Malcolm B. Jones ${ }^{4}$
}

\author{
${ }^{1}$ Sir Alister Hardy Foundation for Ocean Science, The Laboratory, Citadel Hill, Plymouth PL1 2PB, United Kingdom \\ ${ }^{2}$ Observatoire des sciences de l'univers, Laboratoire d'oceanographie biologique et d'ecologie du plancton marin, BP 28, \\ 06234 Villefranche-sur-Mer cedex, France \\ ${ }^{3}$ Marine Biodiversity Group, National Institute of Water and Atmospheric Research (NIWA), Geta Point, PO Box 14-901, \\ Wellington, New Zealand \\ ${ }^{4}$ Department of Biological Sciences, University of Plymouth, Drake Circus, Plymouth PL4 8AA, United Kingdom
}

\begin{abstract}
Long-term changes in the plankton of the North Sea are investigated using data from the continuous plankton recorder (CPR) survey. During the last 4 decades, there appears to have been 2 large anomalous periods within the plankton data set, one that occurred in the late 1970s and the other in the late 1980s. These anomalous periods seem to be largely synchronous with unusual ocean climate conditions that have occurred episodically over a timescale of decades. The unusual ocean climate conditions prevailing at these 2 time periods appear to contain important hydrographical elements that involve oceanic incursions into the North Sea. This paper, using data from the CPR survey and providing evidence from other studies, focuses on the relationship between the long-term changes in the biology of the North Sea and these 2 exceptional hydro-climatic events. Here, we suggest that while atmospheric variability and associated changes in regional temperatures have a dominant effect on the marine environment, oceanic influences on the ecology of a semi-closed environment such as the North Sea may have been underestimated in the past.
\end{abstract}

KEY WORDS: North Sea · Plankton communities $\cdot$ Long-term trends $\cdot$ Continuous plankton recorder · Great salinity anomaly · Ocean climate

Resale or republication not permitted without written consent of the publisher

\section{INTRODUCTION}

In the North Atlantic, the most dominant atmospheric signal is the North Atlantic Oscillation (NAO), which accounts for at least one-third of the annual total variance in sea level pressure (Dickson \& Turrell 2000). Decadal trends in the NAO index influence regional temperatures, precipitation and the degree of wind speed/direction over the North Atlantic (Hurrell 1995). With this climate index integrating a large proportion of variability from a number of meteorological parameters, it has provided a useful tool in the interpreta-

*E-mail: maed@mail.pml.ac.uk tion of long-term biophysical interactions from both marine and terrestrial environments (Ottersen et al. 2001). For example, the oscillations and trends in the NAO index have been reflected in the abundance and spatial distribution of plankton in the northeast Atlantic on a timescale of decades (Fromentin \& Planque 1996). However, some of the most pronounced shifts in the plankton community structure and extreme values (high or low) in plankton populations, particularly in the North Sea, could not be related directly to trends in the NAO index. It has been speculated that occasional extreme climatic events, that contain oceanographic elements, punctuate the decadal trends in the NAO index or enhance its effects 
to such an extent they can take the form of notable biological shifts (Edwards et al. 2001a). In the North Sea, these biological irregularities appear to be largely synchronous with anomalous hydrographic events that have occurred episodically over the last 40 yr. In particular, 2 oceanographic anomalies stand out as exceptional periods. The first period, in the late 1970s, was associated with cold-boreal conditions, while the second period occurred in the late 1980s and was associated with a warm-temperate climate. The relationship between the long-term changes in plankton recorded by the continuous plankton recorder (CPR) survey in the North Sea and these 2 anomalous hydro-climatic events are discussed in this paper.

The CPR survey, which was started in the North Sea in 1931, is one of only a few long-term biological monitoring programmes and the only one at a spatial scale that gives a systematic coverage of the North Sea in space and time. Using biological data recorded by the CPR survey, several planktonic time series were examined, including an assessment of phytoplankton biomass/structure, and components of the holozooplankton and meroplankton communities. This paper focuses predominately on the response of phytoplankton populations to the ocean climate anomalies. Other biological components of the ecosystem and independent studies from single-point stations are also discussed to corroborate and highlight the manifestation of this response through the various marine trophic levels. We found that although these studies also noticed an abrupt change in the North Sea ecosystem during these 2 periods, they did not have the benefit of regional comparisons (Evans \& Edwards 1993, Josefson et al. 1993, Lindeboom et al. 1995, Greve et al. 1996, Kröncke et al. 1998). As a consequence of this, some researchers have presented these changes as evidence of eutrophication in the North Sea rather than far-field North Atlantic hydrographic changes. Here, we suggest that these anomalous ocean climate conditions have far reaching consequences on the ecology of the North Sea and are arguably the principal cause of conspicuous ecosystem shifts rather than trends in atmospheric oscillations or anthropogenic perturbations.

\section{MATERIALS AND METHODS}

The CPR survey is a long-term marine plankton monitoring programme which consists of a network of CPR transects, towed monthly across the major geographical regions of the North Atlantic. On certain standard routes, there is a virtually unbroken monthly coverage going back to 1948. The CPR is a high speed sampler (usually towed between 10 and 18 knots), sampling at a depth of approximately $7 \mathrm{~m}$ using a filtering mesh size of $270 \mu \mathrm{m}$. After each tow, the CPR is returned to the laboratory for routine analysis involving the recorded estimate of phytoplankton biomass (phytoplankton colour index), and the identification (up to 450 different taxa) and quantification of zooplankton and phytoplankton taxa (Warner \& Hays 1994). Using biological data recorded by the CPR survey, a number of plankton time series were examined which included an assessment of phytoplankton biomass/structure and components of the holozooplankton (total copepod abundance) and meroplankton (decapod larvae abundance) communities. The data included approximately 60000 CPR samples taken in the North Sea between 1960 and 1995. The CPR survey's record of phytoplankton biomass (colour index) is assessed by reference to standard colour charts to obtain an estimate of the quantity and density of phytoplankton recorded due to the visual discoloration on the CPR silk produced by the presence of green chlorophyll pigments. The green pigments include the chloroplasts of broken cells and small, unarmoured flagellates which tend to disintegrate when they come in contact with formaldehyde (the storage medium for CPR silks).

For the assessment of trends in the phytoplankton community, principal component analysis (PCA) was performed separately on the diatom and dinoflagellate assemblages. This procedure gave a summary of the dominant information within the phytoplankton data set by explaining the largest amount of variation in the phytoplankton assemblage. The phytoplankton data set included those species recorded at a frequency above $1 \%$ in CPR samples (approximately 20 dinoflagellate and 30 diatom species). Although there are large variances in the sizes of diatoms and dinoflagellates sampled by the CPR survey, this is not thought to bias the sampling, as the percent retention is roughly constant within each species (Robinson 1970). The original data was log transformed to normalise the data and weighted in the PCA analysis by the species variance. Two of the 9 assemblage indicators proposed by Beaugrand et al. (2002) were used to assess long-term trends in sub-arctic and temperate copepod assemblages in the North Sea. The first association was composed of the temperate species: Rhincalanus nasutus, Eucalanus crassus, Centropages typicus, Candacia armata and Calanus helgolandicus. The second species assemblage was composed of sub-arctic species that occur mainly in the sub-arctic gyre, west of Norway and in the northern North Sea: Calanus finmarchicus, Euchaeta norvegica, Heterorhabdus norvegicus and Scolethricella spp. Firstly, the number of species that belong to both assemblages was calculated for each CPR sample in the central North Sea $\left(0-10^{\circ} \mathrm{E}, 53-58^{\circ} \mathrm{N}\right)$. Secondly, as the number of spe- 
cies detected grows with the sampling effort (Beaugrand \& Edwards 2001), a special procedure to guarantee that both time series were unaffected by the difference in sampling throughout the time was applied. For each year, the mean of the number of species per association was calculated by selecting randomly a constant number of CPR samples in the selected spatial window; this in turn was a function of the number of CPR samples in that particular area and the percentage of missing data. The constant number was fixed to 10 . The procedure was applied yearly at 2 mo $(\times 6$ periods) and daylight/dark ( $\times 2$ periods) intervals in order to take into account all important sources of variability (Beaugrand et al. 2001). Finally, the annual mean was calculated if the maximum amount of missing data was $<10$ of the possible 12 available.

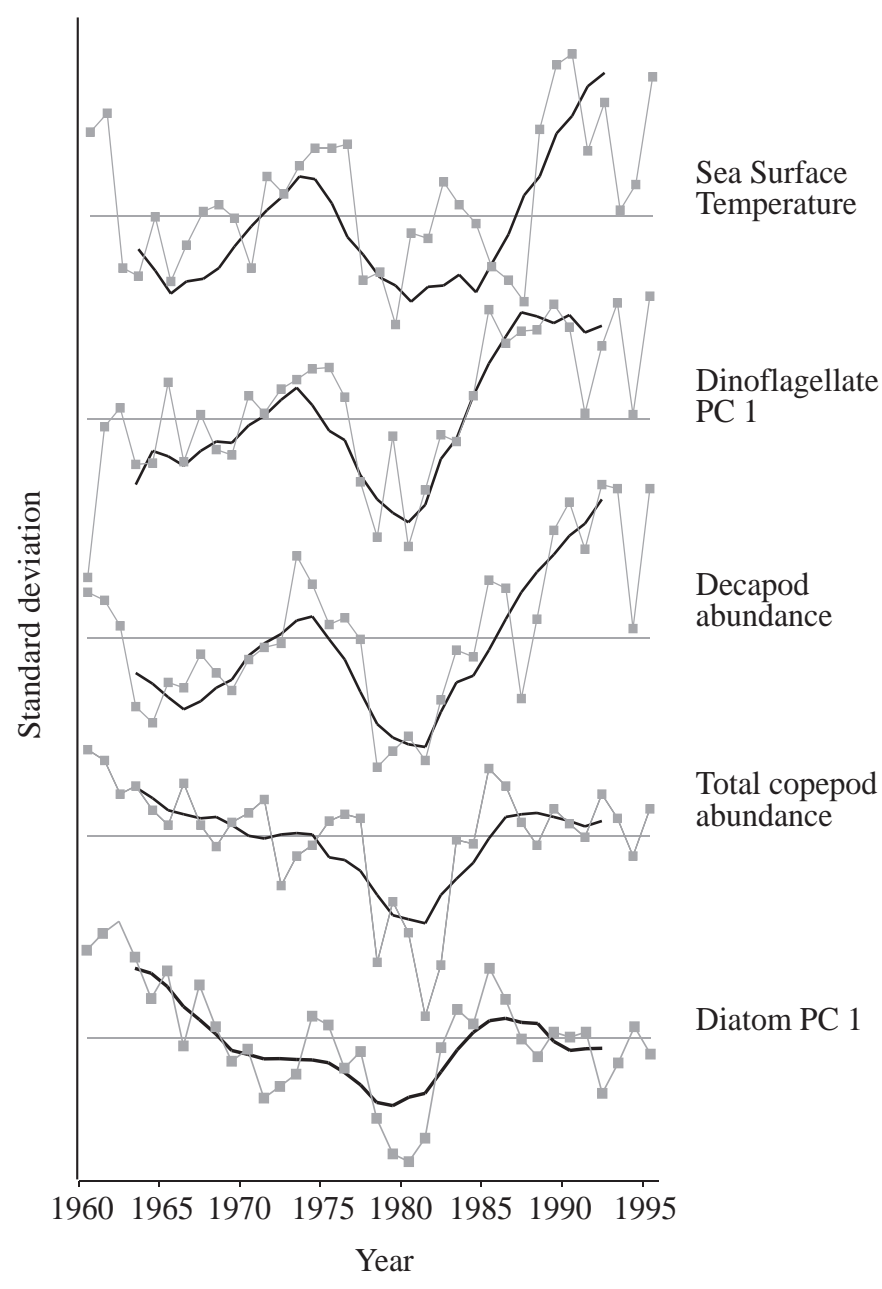

Fig. 1. Sea surface temperature annual and 3 yr running means (bold) (ICES data) for dinoflagellate Principal Component (PC) 1, decapod larvae abundance, total copepod abundance and diatom PC 1 in the North Sea between 1960 and 1995. Data are standardised to 0 mean (horizontal line) and unit variance. Note some similarities between the trends and minimum values seen in the late $1970 \mathrm{~s}$

\section{RESULTS AND DISCUSSION}

\section{The late 1970 s cold-boreal event}

Fig. 1 shows the long-term trends in sea surface temperature (SST) and a number of biological components from the plankton community recorded by the CPR survey in the North Sea from 1960 to 1995 . What is immediately apparent is that all the time series show a significant decline in the late 1970s (Fig. 1). SST and the abundance of phytoplankton and zooplankton were significantly below average between the late 1970s and the early 1980s, and reached their minima at the end of the $1970 \mathrm{~s}$. A large reduction in numbers and average dry weight biomass of zooplankton measured from CPR samples took place in the years 1978 to 1982 . This decline was also evident in the meroplankton community (represented in Fig. 1 by decapod larvae abundance). The decline in the abundance of dinoflagellates and diatoms echoes the minima of annual phytoplankton biomass observed during this period (Fig. 2a). Furthermore, the phytoplankton spring bloom was much lower than average and occurred later compared to the long-term seasonal cycle (Fig. 2b). During this period, phytoplankton diversity (data not shown) was also at a minimum and seasonal patterns were anomalous, which was caused presumably by the delay in the spring bloom and subsequently a retarded seasonal growth period. For example, many early spring diatom species were absent from the spring bloom and one of the most abundant diatoms Chaetocerus spp., which is normally present in March/April, was recorded only in small numbers in August 1979 in the southern North Sea (Edwards et al. 2001b). Temporal niches normally occupied by particular species were, therefore, abnormal during this period. Similarly, one of the most abundant dinoflagellates Ceratium macroceros experienced a population crash, which was particularly apparent in the southern North Sea (Fig. 3a). Fig. 3b shows the average annual recorded frequency of $C$. macroceros on CPR samples in the southern North Sea and a drop in recorded frequency of $40 \%$ in the 1960 s to $0.4 \%$ during the late $1970 \mathrm{~s}$. A possible explanation for this is that $C$. macroceros is one of the species which blooms later in the natural seasonal succession of phytoplankton in the North Sea and usually peaks in abundance between August and October. The knock-on effect of species appearing much later in the seasonal cycle during the late 1970s could have eventually squeezed C. macroceros out of its normal temporal niche. However, this does not completely explain why $C$. macroceros never quite fully recovered from this event in the southern North Sea when the season returned to normal. It is possible, however, 
(a)

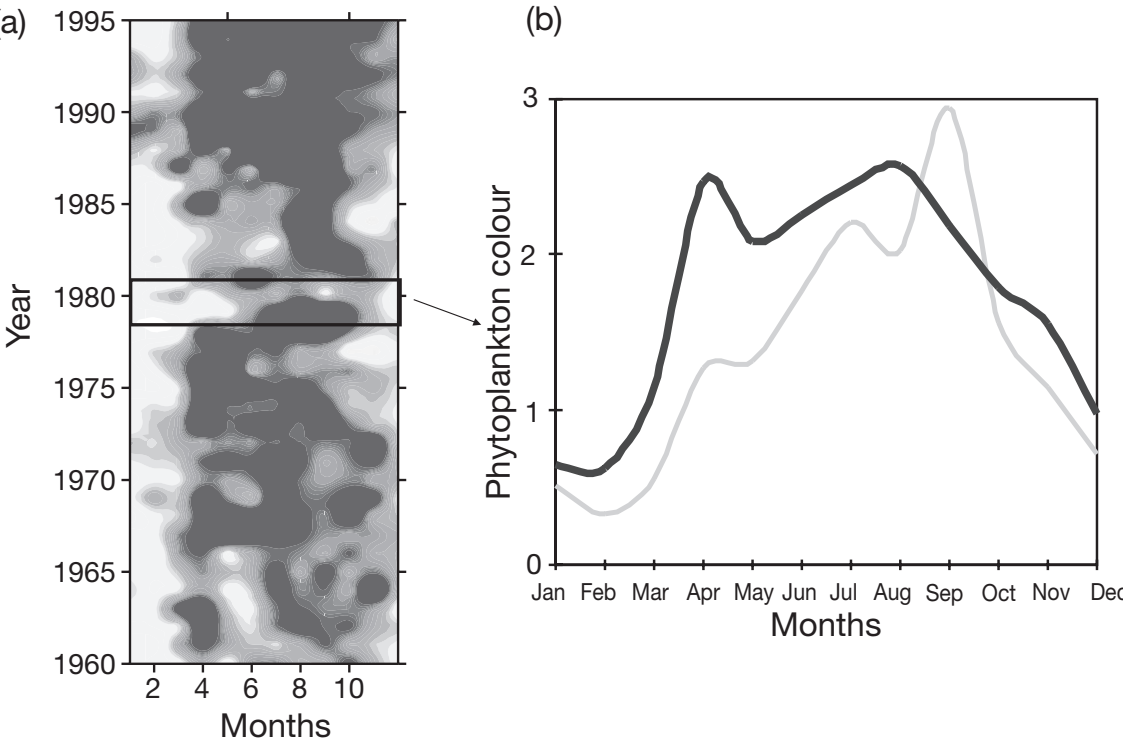

Fig. 2. (a) Phytoplankton biomass monthly means contour diagram (continuous plankton recorder [CPR]-survey asessment of phytoplankton colour index) in the North Sea from 1960 to 1995. (b) Differences in phytoplankton biomass for the long-term seasonal cycle between 1960 and 1995 (dark line) and the seasonal cycle between 1978 and 1980 (light line). Note the late development of the seasonal cycle and a less conspicuous spring bloom during the late 1970s and early 1980s (boxed area in [a])

that C. macroceros may have lost its niche momentarily only to be replaced by another competitor.

The late 1970s was obviously an exceptional period amongst the plankton of the North Sea recorded by the CPR survey. It is therefore perhaps no coincidence that this period was also marked by an equally exceptional ocean climate event known as the 'great salinity anomaly' (GSA) (Dickson et al. 1988). This event has been well documented by oceanographers and is possibly the most exceptional hydrographic event to have occurred in the North Atlantic this century along with a similar anomaly in 1910 (Belkin et al. 1998). The GSA was an oceanic anomaly observed in the North Atlantic from 1968 to 1982, and was associated with a minima in salinity (and temperature) which was observed by various ocean weather ships and time series around the North Atlantic during this period. Essentially, Dickson et al. (1988) suggested that a pulse of cold, low salinity water, originally formed in the midto late 1960s in the East Greenland Sea (caused by enhanced ice transport into the Arctic Basin), proceeded to circulate around the North Atlantic's subpolar gyre reaching the west of the British Isles in 1975; thereby, explaining the lag in timing of the anomaly in different regions of the North Atlantic. Edwards et al. (2001a) noted that the phytoplankton biomass recorded by the CPR in different regions of the North Sea reached their minima in accordance with the proposed transit dates of the GSA into the North Sea: offshore northern North Sea, minimum phytoplankton biomass 1976, transit of salinity anomaly 1976 to 1977; central and British coastal North Sea, minimum phytoplankton biomass 1977, transit of salinity anomaly 1977 to 1978 ; southern continental North Sea, minimum phytoplankton biomass 1979, transit of salinity anomaly 1979 .

There is physical evidence to suggest that the period in the late 1970s/early 1980s was anomalous in the North Sea and was characterised by reduced temperatures and salinities (Turrell et al. 1992). In 1977 and 1979, the winters were the coldest recorded for the last 50 yr (Becker \& Pauly 1996) and were particularly harsh in the shallower southern North Sea. Additionally, Turrell et al. (1992) suggested that the salinity anomaly experienced in the North Sea in the late 1970s coincided with a reduced inflow of warm Atlantic water (derived from the Shelf Edge Current and the North Atlantic Current) into the North Sea. A reduced inflow of Atlantic water into the North Sea would also significantly decrease the flux of nutrients entering the North Sea from oceanic sources. Although the passage of the GSA in many ocean-weather ships and time-series for the North Atlantic, for example, the Fair Isle-Munken salinity time series, is clearly visible, its passage into the North Sea is difficult to distinguish from surface salinity data, possibly due to local salinity variations which would dissipate the signal (Edwards et al. 2001a). However, a Norwegian time series clearly showed a negative salinity anomaly entering at depth along the Norwegian trench in 1976 (Aure 1999); the time of an abrupt change in the phytoplankton of the offshore northern North Sea. As the salinity and temperature signal was much stronger in the Norwegian trench than in the northwestern North Sea, this suggests that the main signal in this instance was brought into the North Sea via the Norwegian trench as opposed to the Fair Isle or Dooley currents. Svendsen et al. (1995) also showed a pronounced decline in the areal coverage of Atlantic water ( $>35 \mathrm{psu}$ ) in the northern North Sea from 30 to $50 \%$ in the early 1970 s to $0 \%$ in the late 1970 s. The areal coverage of Atlantic water persisted below $20 \%$ until the late 1980s. Similarly, Becker \& Pauly (1996) noted that the spatial extent of the northern Atlantic inflow (characterised by the 35 psu isohaline) appeared to be limited in the northern North Sea during 
years with negative temperature anomalies (particularly in the late 1970s).

Corten (1990) and Corten \& van de Kamp (1992) suggested that most of the observed changes in the pelagic fish stocks in the North Sea (particularly the dramatic decline of herring in the late 1970s) could be explained by a reduction of Atlantic water and changes to the circulation of the North Sea during this period. For example, the spawning stock was $50000 \mathrm{t}$ in 1977 compared to an estimated $1400000 \mathrm{t}$ in 1990. Corten \& van de Kamp (1996) also mentioned that the entire sprat fishery in the North Sea collapsed in the late 1970s and the distribution

(a) (1) Northern North Sea

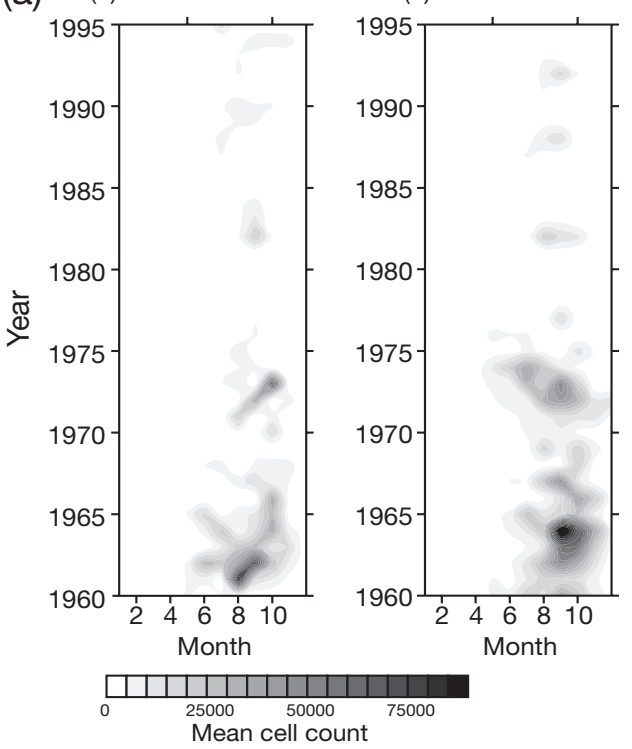

(b)

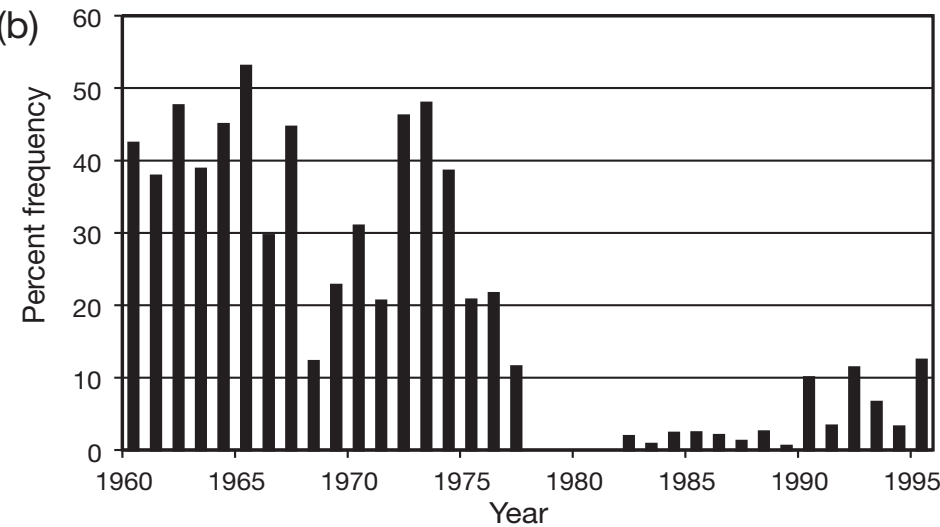

Fig. 3. (a) Ceratium macroceros monthly means for 3 areas of the North Sea (northern, central and southern) from 1960 to 1995. Density equates to mean cell count per sample $\left(\sim 3 \mathrm{~m}^{3}\right)$. (b) Percent frequency of the occurrence of $C$. macroceros in the southern North Sea from 1960 to 1995 on CPR samples. Note the disappearance of C. macroceros for a number of years in the late 1970s and early 1980s. Phytoplankton diversity was also at a minimum during this period and is associated with the largest phytoplankton community shift recorded by the CPR survey between 1960 and 1995 of sprat stock shifted southward. Svendsen et al. (1995) showed that the migration of the western mackerel stock into the North Sea (dependent on Atlantic water transport) was at an all time low in the late 1970s. Additionally, Lindeboom et al. (1995) reported that the abundance of macrobenthos, fish and birds in the southern North Sea showed sudden changes at the end of the late 1970s, and Southward (1980) noted the appearance of cold-water gadoid species in the western English Channel during 1979 which had only once before been previously recorded. Many other researchers also observed an abrupt change in the biology of the North Sea in the late 1970s (Evans \& Edwards 1993, Josefson et al. 1993, Kröncke et al. 1998). For example, from 1978/1979 to 1981, Kröncke et al. (2001) noted a high percentage of arctic-boreal benthic species in the southern North Sea (Island of Norderney, East Frisia, Germany).

Although there is undeniably very strong evidence to suggest something exceptional happened in the North Sea in the late 1970s (from both physical and biological time series data), the question remains as to whether it was due to the GSA event. Apart from the very cold temperatures experienced in the North Sea during the late 1970s (which would explain the decline in some macrobenthos species and increase in boreal species), how else could the GSA affect the ecology of the North Sea? It is possible that the cold, low salinity water could have caused a seasonally persistent thermo-halocline, preventing the renewal of nutrients to the euphotic zone prior to the spring bloom and hence causing its subsequent delay. For example, when the GSA passed through the Rockall Channel it was discernible down to at least $1000 \mathrm{~m}$ (Belkin et al. 1998), creating a very stable water mass and, possibly, disrupting deep-water mixing processes. Lindeboom et al. (1995) speculated that the inflowing oceanic water caused by the GSA had a completely different chemical composition and may have initiated a biological switch in the late 1970s. However, these researchers did not provide any evidence to support this theory. Detailed analysis of nutrient data (phosphate and nitrate) from single-point stations in the North Sea did not identify any significant changes in the late 1970s (Visser et al. 1996). It must be noted, however, that these sampling sites were restricted to coastal areas and, as a consequence, they were possibly influenced predominately by local processes, although Visser et al. (1996) provided some evidence that the behaviour of silicate in the English Channel was possibly related to salinity changes. Other evidence of chemical change was described by 

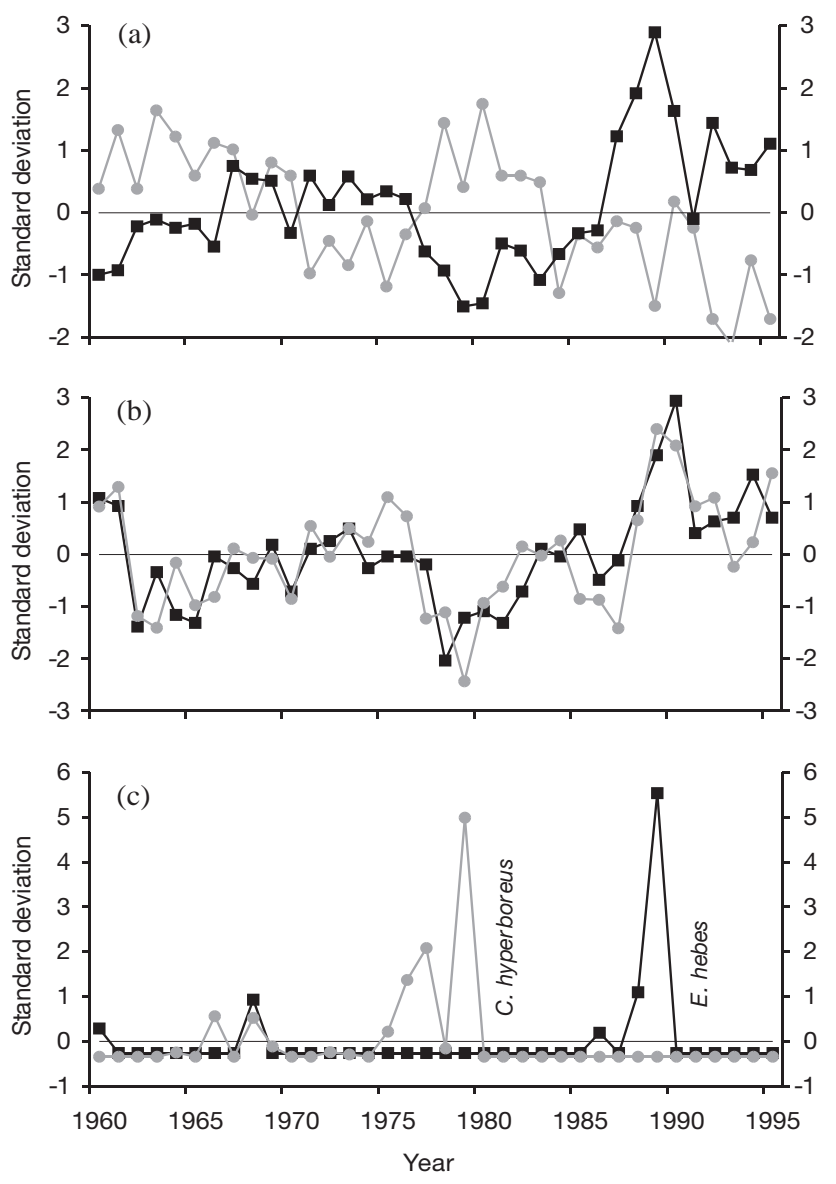

Fig. 4. (a) Occurrence of calanoid copepods associated with sub-arctic environments ( $\bullet$ ) and phytoplankton biomass $(\square)$ in the North Sea from 1960 to 1995. (b) Similarity between sea surface temperature $(\bullet)$ and the occurrence of calanoid copepods ( $\square$ ) associated with warm temperate oceanic environments $(r=0.74, p<0.01)$. The biological trend follows temperature, showing a minimum in the late 1970 s and a maximum in the late 1980s and early 1990s. (c) Abundance of 2 copepod indicator species in the North Sea; arctic-boreal species Calanus hyperboreus ( $\bullet$ ) and the temperate shelf edge species Euchaeta hebes (ם). Neither of these species are naturally resident in the North Sea and can be classed as hydrographic indicator species. This suggests that the late 1970 s event is associated with a cold water incursion from boreal sources and the late 1980s inflow is associated with warmer waters derived from the shelf edge current. Data are standardised to 0 mean (horizontal line) and unit variance

Dooley et al. (1984) who reported that the different water masses passing through the Rockall Channel in the late 1970s had very different chemical properties (particularly silicate). Corten (1990) and Turrell et al. (1996) suggested that the circulation changes in the North Sea, rather than the direct effect of variations in temperature and salinity, caused the ecological changes (particularly pelagic fish stocks) seen in the North Sea during the late 1970s.
If a cold body of water was advected into the North Sea during the late 1970s, there should be some evidence from indicator species recorded by the CPR survey. Fig. 4a shows the occurrence of sub-arctic zooplankton species recorded in the North Sea from 1960 to 1995 . Since the 1960 s, the occurrence of sub-arctic species in the North Sea has declined steadily; however, there was a peak in occurrence during the late 1970s and early 1980s (Fig. 4a). The occurrence of zooplankton species associated with warm temperate oceanic conditions was at an all time low in the North Sea during this period (Fig. 4b). Fig. 4c shows the occurrence of the arctic-boreal indicator species Calanus hyperboreus reaching unprecedented levels in the North Sea in the late 1970s. Other cold water species also reached a peak at this time; for example, Ceratium longipes was found 5 standard deviations above the long-term mean abundance in 1979. During this year, especially in the southern North Sea, virtually all other phytoplankton species were found in very low abundance and some were not recorded by the CPR survey. Other sub-arctic species, not resident in the North Sea, however, reached all time high levels during the late $1970 \mathrm{~s}$. The marine diatom Navicula planamembranacea is normally found in the arctic-boreal Atlantic particularly around Iceland and Greenland, and must have entered the North Sea during this period through advection (being a passive drifter). Similarly, the large marine copepods Metridia longa, Euchaeta norvegica and Calanus hyperboreus could only have entered the North Sea through advection. These latter species tend to spend most of their life-cycle in deeper waters (500 to $1000 \mathrm{~m}$ ) and only migrate to the surface during spring, spending a couple of months in the euphotic zone. Although these species are more abundant in the colder waters of the northwest Atlantic, they are also found in the colder waters off the Norwegian coast (data from CPR survey). One of the few ways in which these species can enter the North Sea is along the Norwegian trench and C. hyperboreus has been found as far south as the entrance of the Skagerrak (CPR samples from 1979). Hydrographic stations in the entrance of the Skagerrak confirm that the period from 1977 to 1981 was marked by a very unusual negative salinity anomaly (Danielssen et al. 1996).

Although one of the possible explanations for the presence of these species in the North Sea is through advection, probably, entering the North Sea at depth along the Norwegian trench, it is unlikely that they were advected from the northwest Atlantic following the route of the GSA advective hypothesis suggested by Dickson et al. (1988). This theory would mean that populations of these species would have had to have spent up to 10 yr travelling around the sub-polar gyre before they entered the North Sea. It is more likely that these species originated 
from off the Norwegian coast and entered the North Sea from a more northerly or easterly route. Alternatively, when the warm Atlantic inflow was weakest, colder water from the north penetrated farther into the North Sea. It is worth noting that during the period from 1976 to 1982, the Barents Sea had severe ice conditions (Aure 1999), perhaps indicating a decrease in Atlantic water transported north through the Nordic Seas.

An alternate GSA hypothesis was suggested by Dooley et al. (1984) who speculated that the GSA and temperature anomaly to the west of the British Isles observed in the late 1970s, was caused by a large-scale shift eastwards of the Polar Front. While Hansen \& Kristiansen (1994) did not disagree with Dickson et al. (1988) on how the anomaly travelled from one region to another in the northwest Atlantic, they did disagree on how the anomaly appeared in the northeast Atlantic. They suggested that the North Atlantic Current and Shelf Edge Current transports a positive salinity signal to the northeast Atlantic (Faroe-Shetland region), while the East Icelandic Current (originating north of Iceland) transports a negative signal. A change in the balance between the flows, with weakened Atlantic water relative to the East Icelandic Current, could explain the GSA event in this region (Hansen \& Kristiansen 1994). Turrell et al. (1996) also supported this hypothesis and suggested that when less Atlantic water enters the Faroe-Shetland Channel, a greater proportion of water at all depths is derived from the lower salinity water originating from the northern sources. There is also evidence that the East Icelandic Current has, on occasions, penetrated as far down as the coast of mid-Norway (Skjoldal et al. 1993) but it is not clear how these intrusions affect Atlantic inflow into the North Sea. Blindheim et al. (1996) suggested that the increased supply of Arctic waters from the East Icelandic Current during the late 1970s, considerably reinforced the GSA in the Nordic Seas, particularly in the southern Norwegian Sea. If this is true, it is more likely that the indicator species were advected into the North Sea during one of these periods rather than by the sub-polar gyre circulation, or that when the warm Atlantic inflow was weakest, colder water from the north penetrated farther into the North Sea. Although there are disagreements on the explanations for the GSA, it is still undoubtedly one of the most important oceanographic events to have occurred in the North Atlantic during the last 50 yr. Furthermore, Blindheim et al. (1996) suggested that the salinity anomalies in the Northeast Atlantic (particularly in the Nordic Seas) were not only caused by changes in the sub-polar gyre circulation but also by the direct influence of the East Icelandic Current. These changes in the oceanography of the North Atlantic were most likely responsible for a cold-boreal period in the North
Sea during the late 1970s, which manifested itself through the many observed changes in the biology of the North Sea during this time.

\section{The late 1980s warm-temperate event}

In contrast, the late 1980 s warm-temperate event was, as the name would suggest, the reverse of the late 1970s cold-boreal event, with the North Sea characterised by high salinities and temperatures as opposed to cold, low salinity conditions seen in the late 1970s. From 1988 onwards, the NAO index increased to the highest positive level observed in the 20th century. This, coupled with evidence for an increased inflow of relatively warm Atlantic water into the North Sea, conspired to produce an extremely warm oceanic climate for the North Sea during the late 1980s and early 1990s period. While SST changes in the North Sea can be explained chiefly by local air-sea exchange processes, which depend on the North Atlantic atmospheric circulation (measured by the NAO index), larger SST anomalies (positive or negative) are related to salinity anomalies in the eastern North Atlantic and North Sea (Becker \& Pauly 1996). In the area around the British Isles, the winter of 1988/1989 was exceptionally mild, with average North Sea surface temperatures ranging between 1 and $3^{\circ} \mathrm{C}$ above normal and air temperatures up to $+2.5^{\circ} \mathrm{C}$ above the anomaly with respect to those between 1961 and 1990 (Hadley Centre, UK climate database, pers. comm.). Positive anomalies in air temperatures over the British Isles and SST in the North Sea persisted through the rest of the year. According to Norwegian coastal SST data, the winter of 1990 was probably the warmest since measurements started in 1870 (Danielssen et al. 1996). Becker \& Dooley (1995) reported that during the late 1980s and early 1990s, salinity levels in the English Channel, southern North Sea and western German Bight were extremely high. Heath et al. (1991) also reported an inflow of water with exceptionally high salinity in January 1990 off the Norwegian coast ( 58 to $59^{\circ} \mathrm{N}, 3.5$ to $4.0^{\circ} \mathrm{E}$ ). These values exceeded anything recorded previously by the Marine Laboratory, Aberdeen, since records began in 1920. A high peak in salinity occurred in 1989 in the time series of mean salinities along the Fair Isle-Munken section (Belkin et al. 1998). Turrell et al. (1996) also noted a high salinity event in the late 1980s in the Faroe-Shetland channel, and Danielssen et al. (1996) reported that between 1989 and 1993, the entrance of the Skagerrak was characterised by unusually high salinities. Sundermann et al. (1996) suggested that the relatively fast transition of salinity and temperature from the late 1970s to the late 1980s could have indicated a hydrographical regime shift.

The biological response to the late 1980s and early 1990s event was exceptional. In 1989, phytoplankton 

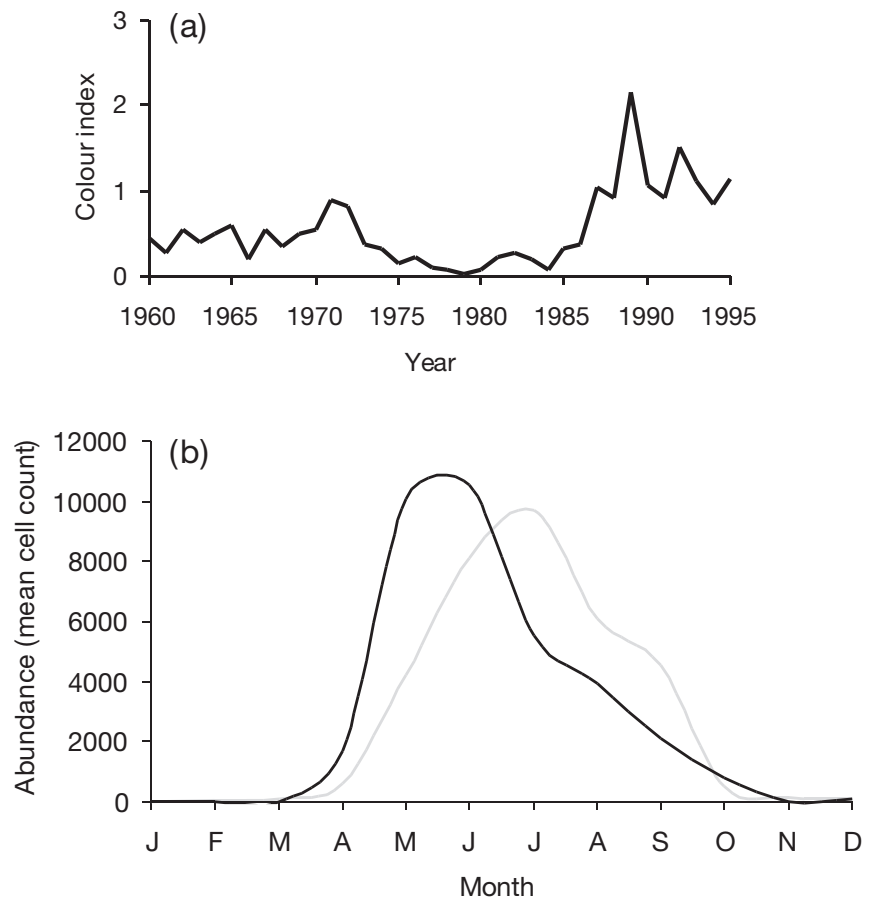

Fig. 5. (a) CPR-survey assessment of phytoplankton biomass (colour index) during the winter months (December, January, February) in the North Sea from 1960 to 1995. (b) An example of the phenological changes seen in the plankton recorded by the CPR survey since the late 1980s. The graph shows the long-term seasonal cycle of Protoperidinium spp. (light line) from 1960 to 1988 and the seasonal cycle from 1989 to 1995 (dark line). Note the trend for the common dinoflagellate species to appear earlier in the year during the 1990s

biomass measured by the CPR survey was nearly 3 standard deviations above the long-term mean (Fig. 4a), its highest value in the North Sea since records began in 1948. The rise in phytoplankton biomass was particularly apparent during the winter months which showed a $>90 \%$ increase (Fig. 5a). Data from the CPR survey (not shown) showed that during this period, the North Sea ecosystem was punctuated by a succession of shortlived exceptional phytoplankton blooms, including the oceanic diatom Thalassiothrix longissima (Reid et al. 1992). Many of the phytoplankton species recorded their highest monthly values (monthly values from January 1960 to December 1995) and peaked in abundance 1 to 3 mo in advance of their normal seasonal peak. Turrell et al. (1992) have suggested that the Atlantic inflow into the North Sea makes a major contribution to the input of generally warmer, nutrient rich water into the northern North Sea. It is estimated that close to $90 \%$ of the inputs to the North Sea of both the major nutrients nitrate and phosphate needed for phytoplankton growth derive from the North Atlantic (NSTF 1993). Variability of the Atlantic inflow into the North Sea could, therefore, have profound implications for the circulation and ecology of the North Sea. There is some evidence from data recorded in the Skagerrak that pronounced changes in nutrient levels did occur in the late 1980s (Dahl \& Danielsen 1992). The North Sea also experienced an influx of unprecedented numbers of oceanic species, including oceanic tunicates (Lindley et al. 1990). Fig. 4b shows zooplankton species associated with warm temperate oceanic conditions reaching a peak in the North Sea in the late 1980s and early 1990s (closely comparable with the rise in temperature). Fig. 4c shows a peak in the abundance of the copopod species Euchaeta hebes occurring in the late 1980s. This species is not a natural resident in the North Sea and is associated with oceanic shelf edge waters to the west of the British Isles. It is therefore possible that the inflowing Atlantic water was derived from a more southerly origin and was carried north by the shelf edge current (Edwards et al. 1999). Kröncke et al. (1998) reported a sudden increase in macrofaunal biomass in the southern North Sea during the late 1980s and Greve et al. (1996) noticed a high number of oceanic plankton species in the Helgoland Roads time series during this period. Beukema (1992) suggested that the structural changes observed in the macrobenthos community in the southern North Sea (Wadden Sea) during the prolonged period of mild winters experienced in the late 1980s were more serious than those observed during a decade of eutrophication.

Data on fish stocks also suggest that there was an increased inflow of oceanic water, originating from along the continental slope, into the North Sea. For example, researchers have noticed the northward progression of tropical species along the continental shelf west of Ireland since the late 1980s (e.g. Quero et al. 1998). An invasion by blue-mouth Helicolenus dactylopterus in the northern North Sea took place in 1990/91 (Heessen et al. 1996). This species is usually found at depths of 200 to $800 \mathrm{~m}$ on the lower continental shelf to the west of the British Isles. Reports of blue-mouth occurring in the North Sea during the last century are very rare; however, since 1991, it has been caught along a wide distribution in the North Sea, possibly as a result of changes in larval drift (Heessen et al. 1996). Changes in the distribution of the herring Clupea harengus around this time have also been observed (Corten \& van de Kamp 1992). Additionally, the capture of horse mackerel Trachurus trachurus dramatically rose in the North Sea from the late 1980s onwards and this is apparently connected with the increased transport of Atlantic water into the North Sea (Reid et al. 2001). The major changes in the North Sea observed during this period were thought to be of such significant magnitude to have been termed a 'regime shift' (Reid et al. 2001). Since the late 1980s, phytoplankton biomass (Fig. 5a) has remained high in the North Sea, particularly in winter, and there have been many examples of phenological changes taking place 
within the plankton assemblage (Fig. 5b). The persistence of continually high phytoplankton biomass and permanent shifts in seasonal cycles throughout the 1990s, may indicate a more permanently established ecological regime in the North Sea. The changes seen in the plankton during the 1990s, may have been heralded by the late 1980s anomaly, which could turn out to be more than a mere transient event, and may give credence to the regime shift hypothesis.

\section{CONCLUSIONS}

While atmospheric variability plays a key role in the overall long-term and regional patterns of plankton (Fromentin \& Planque 1996, Edwards et al. 2001a), oceanic influences on the North Sea ecosystem have been underestimated in the past. The biological irregularities and large plankton community shifts recorded by the CPR survey are associated with anomalous oceanographic events seen during the late 1970s and early 1980s and the late 1980s and early 1990s. The period in the late 1970s and early 1980s was anomalous in the North Sea, characterised by reduced salinities and temperatures caused primarily by the unusual hydroclimatic conditions and a change in the overall North Atlantic current dynamics. In the North Sea during the late 1970s, there was an initial reduction in inflow of Atlantic water, which was followed by a salinity anomaly and changes to the circulation of the North Sea (Corten 1990, Turrell et al. 1992). A reduction in the inflow of generally warmer North Atlantic current waters and the arrival of the GSA in the North Sea would have conspired together to produce a cold-boreal climate within the North Sea. This physical switch may have been initiated by a decrease in flow by the North Atlantic Current, thus, allowing an opening for colder waters from the north to penetrate farther southward. An opposite scenario occurred in the late 1980s, with the North Sea characterised by high temperatures and salinities. The strong westerly wind component in the late 1980 s (caused by high positive NAO values) produced high air temperatures around the British Isles. This, coupled with evidence for an increased inflow of warm, southerly derived Atlantic water into the North Sea (possibly via the Shelf Edge Current), conspired to produce an extremely warm oceanic climate for the North Sea during the late 1980s and early 1990s period.

From the evidence presented in this paper, major ecosystem changes took place around both of these physically anomalous periods that affected all trophic levels from phytoplankton to fish. The 2 periods seem to have been characterised by oceanic incursions into the North Sea, one boreal in origin the other lusitanian. While the largely synchronous changes in the ecosys- tem of the North Sea around these 2 periods may suggest a link between the biology and oceanic inflow into the North Sea, it is largely unclear as to which mechanisms are responsible for the observed changes. For example, it is still open to question as to whether the biological changes are associated with a temperaturemediated response, circulatory changes within the North Sea, chemically driven changes via oceanic influxes or a combination of many factors. There is certainly strong evidence to suggest that large structural changes observed in the macrobenthos community of the southern North Sea can be explained by the severity (late 1970s) and mildness (late 1980s) of winters (Beukema 1992). This could not, however, solely explain all the ecological changes observed during these 2 events. It is also still not known whether the phytoplankton mediated bottom-up control or whether the trophic levels were simply responding to the same environmental stimulus, although there is some evidence of a lag element between phytoplankton and benthic time series. Despite this, we still suggested that these anomalous ocean climate conditions have far reaching consequences on the ecology of the North Sea and are arguably the principal cause of conspicuous ecosystem shifts rather than trends in atmospheric oscillations or anthropogenic perturbations. Furthermore, we conclude that while the volume of oceanic water entering the North Sea is of considerable ecological importance, the original source of this water, from processes farther afield, maybe equally or more so.

Acknowledgements. The CPR survey is supported by a funding consortium comprising: Intergovernmental Oceanographic Commission (IOC), United Nations Industrial Development Organisation (UNIDO), the European Commission and agencies from Canada, Denmark, The Netherlands, United Kingdom and USA. The survey depends on the voluntary co-operation of owners, masters and crews of merchant vessels which tow the CPRs on regular routes. We wish to thank CPR survey team past and present.

\section{LITERATURE CITED}

Aure J (1999) Havets miljo 1999. Fisken Havet 2:1-104

Beaugrand G, Edwards M (2001) Comparison in pelagic communities of sample-size dependence of diversity indices. Oceanol Acta 24:467-477

Beaugrand G, Ibañez F, Lindley JA (2001) Geographical distribution and seasonal and diel changes of the diversity of calanoid copepods in the North Atlantic and North Sea. Mar Ecol Prog Ser 219:189-203

Beaugrand G, Ibañez F, Lindley JA, Reid PC (2002). Diversity of calanoid copepods in the North Atlantic and adjacent seas: biogeography and species associations. Mar Ecol Prog Ser 232:179-195

Becker G, Dooley H (1995) The 1989/91 High Salinity Anomaly in the North Sea and adjacent areas. Ocean Challenge 6:52-57 
Becker G, Pauly M (1996) Sea surface temperature changes in the North Sea and their causes. ICES J Mar Sci 53: 887-898

Belkin IM, Levitus S, Antonov J, Malmberg A (1998) 'Great Salinity Anomalies' in the North Atlantic. Prog Oceanogr 41:1-68

Beukema JJ (1992) Expected changes in the Wadden Sea benthos in a warmer world: lessons from periods with mild winters. Neth J Sea Res 30:73-79

Blindheim J, Borovkov V, Hansen B, Malmberg SA, Turrell WR, Osterhus S (1996) Recent upper layer cooling and freshening in the Norwegian Sea. ICES-CM 1996/C 7:12

Corten A (1990) Long-term trends in pelagic fish stocks of the North Sea and adjacent waters and their possible connection to hydrographic changes. Neth J Sea Res 25:227-235

Corten A, van de Kamp G (1992) Natural changes in pelagic fish stocks of the North Sea in the 1980s. ICES Mar Sci Symp 195:402-417

Corten A, van de Kamp G (1996) Variation in the abundance of southern fish species in the southern north sea in relation to hydrography and wind. ICES J Mar Sci 53:1113-1119

Dahl E, Danielssen DS (1992) Long term observations of oxygen in the Skagerrak. ICES Mar Sci Symp 195:455-461

Danielssen DS, Svendsen E, Ostrowski M (1996) Long-term hydrographic variation in the Skagerrak based on the section Torungen-Hirtshals. ICES J Mar Sci 53:917-925

Dickson RR, Turrell WR (2000) The NAO: the dominant atmospheric process affecting oceanic variability in home, middle and distant waters of European Salmon. In: Mills D (ed) The ocean life of Atlantic salmon: environmental and biological factors influencing survival. Fishing News Books, Blackwell Science, Oxford, p 93-115

Dickson RR, Meincke J, Malmberg SA, Lee AJ (1988) The 'Great Salinity Anomaly' in the northern North Atlantic 1968-82. Prog Oceanogr 20:103-151

Dooley HD, Martin JHA, Ellett DJ (1984) Abnormal hydrographic conditions in the Northeast Atlantic during the 1970s. Rapp P-V Reun Cons Int Explor Mer 185:179-187

Edwards M, John AWG, Hunt HG, Lindley JA (1999) Exceptional influx of oceanic species into the North Sea in late 1997. J Mar Biol Assoc UK 79:737-739

Edwards M, Reid PC, Planque B (2001a) Long-term and regional variability of phytoplankton biomass in the northeast Atlantic (1960-1995). ICES J Mar Sci 58:39-49

Edwards M, John AWG, Johns DG, Reid PC (2001b) Casehistory and persistence of a non-indigenous diatom (Coscinodiscus wailesii) in the north-east Atlantic. J Mar Biol Assoc UK 81:207-211

Evans F, Edwards A (1993) Changes in the zooplankton community off the coast of Northumberland between 1969 and 1988 , with notes on changes in the phytoplankton and benthos. J Exp Mar Biol Ecol 172:11-29

Fromentin JM, Planque B (1996) Calanus and environment in the eastern North Atlantic. 2. Influence of the North Atlantic Oscillation on Calanus finmarchicus and C. helgolandicus. Mar Ecol Prog Ser 134:111-118

Greve W, Reiners F, Nast J (1996) Biocoenotic changes of the zooplankton in the German Bight: the possible effects of eutrophication and climate. ICES J Mar Sci 53:951-956

Hansen B, Kristiansen R (1994) Long-term changes in the Atlantic water flowing past the Faeroe Islands. ICES-CM 1994/S 4:1-16

Heath MR, Henderson EW, Slesser G (1991) High salinity in the North Sea. Nature 352:116

Heessen HJL, Hislop JRG, Boon TW (1996) An invasion of the North Sea by blue-mouth Helicolenus dactylopterus (Pisces, Scorpaenidae). ICES J Mar Sci 53:874-877
Hurrell JW (1995) Decadal trends in the North Atlantic Oscillation: regional temperatures and precipitation. Science 269:676-679

Josefson AB, Jensen JN, Aertebjerg G (1993) The benthos community structure anomaly in the late 1970s and early 1980 s - a result of a major food pulse? J Exp Mar Biol Ecol 172:31-45

Kröncke I, Dippner JW, Heyen H, Zeiss B (1998) Long-term changes in macrofaunal communities off Norderney (East Frisia, Germany) in relation to climate variability. Mar Ecol Prog Ser 167:25-36

Kröncke I, Zeiss B, Rensing C (2001) Long-term variability in macrofaunal species composition off the Island of Norderney (East Frisia, Germany) in relation to changes in climate and environmental conditions. Senckenb Marit 31: $65-82$

Lindeboom HJ, van Raaphorst W, Beukema J, Cadee G, Swennen C (1995) (Sudden) changes in the North Sea and Wadden Sea: oceanic influences underestimated. Dtsch Hydrogr Z 2:86-100

Lindley JA, Roskell J, Warner AJ, Halliday NC, Hunt HG, John AWG, Jonas TD (1990) Doliolids in the German Bight in 1989: evidence for exceptional inflow into the North Sea. J Mar Biol Assoc UK 70:679-682

NSTF (North Sea Task Force) (1993) North Sea quality status report 1993. Olsen \& Olsen, Fredensborg, Denmark

Ottersen G, Planque B, Belgrano A, Post E, Reid PC, Stenseth NC (2001) Ecological effects of the North Atlantic Oscillation. Oecologia 128:1-14

Quero JD, Du Buit MH, Vayne JJ (1998) Les observations de poissons tropicaux et al rechauffement des eaux dans l'Atlantique europeen. Oceanol Acta 21:345-351 (Abstract in English)

Reid PC, Surey-Gent SC, Hunt HG, Durrant AE (1992) Thalassiothrix longissima, a possible oceanic indicator species in the North Sea. ICES Mar Sci Symp 195:268-277

Reid PC, Borges MF, Svendsen E (2001) A regime shift in the North Sea circa 1990. Fish Res 50:163-171

Robinson GA (1970) Continuous Plankton Records: variation in the seasonal cycle of phytoplankton in the north Atlantic. Bull Mar Ecol 6:333-345

Skjoldal HR, Noji TT, Giske J, Fossa JH, Blindheim J, Sundby $S$ (1993) Science plan for research on marine ecology of the Nordic Seas 1993-2000. GLOBEC, Institute of Marine Science, Bergen

Southward AJ (1980) The Western English Channel-an inconstant ecosystem? Nature 285:361-366

Sundermann J, Becker G, Damm P, van den Eynde D and 8 others (1996) Decadal variability of the Northwest European Shelf. Dtsch Hydrogr Z 48:365-400

Svendsen E, Aglen A, Iversen SA, Skagen DW, Smestad O (1995) Influence of climate on recruitment and migration of fish stocks in the North Sea. Can Spec Publ Fish Aquat Sci 121:641-653

Turrell WR, Henderson EW, Slesser G, Payne R, Adams RD (1992) Seasonal changes in the circulation of the northern North Sea. Cont Shelf Res 12:257-286

Turrell WR, Slesser G, Payne R, Adams RD, Gillibrand PA (1996) Hydrography of the East Shetland Basin in relation to decadal North Sea variability. ICES J Mar Sci 53:899-916

Visser M, Battern S, Becker G, Bot P and 12 others (1996) Time series of monthly mean data of temperature, salinity, nutrients, suspended matter, phyto and zooplankton at eight locations on the northwest European shelf. Dtsch Hydrogr Z 48:299-323

Warner AJ, Hays GC (1994) Sampling by the Continuous Plankton Recorder survey. Prog Oceanogr 34:237-256 